\title{
The fate of fluids released from subducting slab in northern Cascadia
}

\author{
K. Ramachandran ${ }^{1}$ and R. D. Hyndman ${ }^{2}$ \\ ${ }^{1}$ Department of Geosciences, The University of Tulsa, Tulsa, OK, USA \\ ${ }^{2}$ Pacific Geoscience Centre, Geological Survey of Canada, Sidney, B.C., Canada \\ Correspondence to: K. Ramachandran (kr@utulsa.edu)
}

Received: 6 October 2011 - Published in Solid Earth Discuss.: 21 October 2011

Revised: 8 March 2012 - Accepted: 23 March 2012 - Published: 17 April 2012

\begin{abstract}
Large amounts of water carried down in subduction zones are driven upward into the overlying forearc upper mantle and crust as increasing temperatures and pressure dehydrate the subducting crust. Through seismic tomography velocities we show (a) the overlying forearc mantle in northern Cascadia is hydrated to serpentinite, and (b) there is low Poisson's ratio at the base of the forearc lower crust that may represent silica deposited from the rising fluids. From the velocities observed in the forearc mantle, the volume of serpentinite estimated is $\sim 30 \%$. This mechanically weak hydrated forearc region has important consequences in limits to great earthquakes and to collision tectonics. An approximately 10 $\mathrm{km}$ thick lower crustal layer of low Poisson's ratio $(\sigma=0.22)$ in the forearc is estimated to represent a maximum addition of $\sim 14 \%$ by volume of quartz $(\sigma=0.09$ ). If this quartz is removed from rising silica-saturated fluids over long times, it represents a significant addition of silica to the continental crust and an important contributor to its average composition.
\end{abstract}

\section{Introduction}

Very large amounts of water are carried down into the Earth in subduction zones of high-porosity oceanic crust, hydrated crustal minerals, entrained sediments, and serpentinized oceanic uppermost mantle. The global ocean may be cycled through subduction zones about every billion years (e.g. Ingebritsen and Manning, 2002; Bounama et al., 2001; Jambon, 1994). With increasing temperature and pressure in the downdip side, dehydration reactions release water upward into the overlying mantle and crust (e.g. Ingebritsen and Manning, 2002; Peacock, 1990; Schmidt and Poli, 1998; Rüpke et al., 2004). For old cold subducting plates, most water is inferred to be expelled under the arc and backarc; for young and hot subduction zones, most water is concluded to be expelled upward beneath the forearc (e.g. Peacock, 1990; Hacker et al., 2003). Cascadia provides an opportunity to study the fluid budget for an exceptionally young and hot subduction zone. We provide new quantitative information on the fate of that water rising into the forearc based on Pand S-wave velocities from 3-D seismic tomography.

In this article we determine the distribution and concentrations of (a) serpentinite in the forearc mantle inferred to be generated through hydration by water rising from the subducting slab, and (b) silica in the forearc lower crust that may be deposited from rising silica-saturated aqueous fluids. The formation of hydrated serpentinite from forearc peridotite mantle reduces the velocity and increases the Poisson's ratio which allows the concentration to be estimated. From the serpentinite concentrations we estimated the total rising water incorporated into the forearc. These total fluid amounts were then compared to the water estimated to have been expelled from the downgoing slab as a function of depth, based on subduction thermal models combined with laboratory-based metamorphic dehydration P-T conditions.

The tomographic velocities also allow definition of Poisson's ratio in the deep forearc crust. As discussed below, there is indication of very low Poisson's ratio. Low Poisson's ratio is uncommon in crustal rocks; only quartz has a very low ratio and the values can be interpreted as a region of high silica content due to rising silica saturated fluids from 
the subducted slab (e.g. Manning, 1996; Peacock and Hyndman, 1999). This interpretation is consistent with the conclusions of Breeding and Argue (2002) on forearc silica from rising silica-saturated fluids, based on studies of outcrop data in a deeply exposed forearc section.

$\mathrm{P}$ - and S-wave 3-D velocity models constructed from earthquake seismic tomography were combined to estimate the reduction in velocities and change in $\mathrm{Vp} / \mathrm{Vs}$ (and Poisson's ratio). The velocity data were then compared to laboratory-based velocities and $\mathrm{Vp} / \mathrm{Vs}$ as a function of volume percent serpentinization (antigorite) in the forearc mantle, and percent quartz in the forearc lower crust. From the percent serpentinite, the amount of total water present in a unit column of the forearc mantle was computed and related to the fluid expulsion rate for the dehydrating Juan de Fuca plate reported in earlier studies. Similarly, from the percent quartz estimated for the lower crust, the amount of total water that must have passed upward through the region to produce this silica was computed.

The serpentinite estimated was $\sim 30 \%$ ( $\mathrm{Vp}=7.6$, $\mathrm{Vs}=4.2$ ). Just seaward of the arc this hydration equals the estimated total amount of water released from the underlying downgoing plate in the recent $\sim 43$ Ma subduction phase. Similar forearc mantle serpentinization has been reported at $40-60 \mathrm{~km}$ depths in SW Japan by Zhao et al. (2011). Xia et al. (2008) calculated 20-30\% serpentinization for the mantle wedge of Kyushu in SW Japan. Savov et al. (2007) provide a discussion of serpentinized peridotites from the Mariana forearc.

A $\sim 10 \mathrm{~km}$ thick lower crustal layer of low Poisson's ratio $(0.22 ; \mathrm{Vp} / \mathrm{Vs} 1.65)$ corresponds to $\sim 20 \%$ quartz. If this quartz is removed from rising silica-saturated fluids over long times, it represents a significant addition of silica to the continental crust and an important contributor to its average composition.

\section{Structure of the nothern Cascadia}

At the northern Cascadia continental margin, the Juan de Fuca plate subducts at a rate of about $45 \mathrm{~mm} \mathrm{yr}^{-1}$ in a northeasterly direction (Fig. 1). The young age of the incoming plate of about $8 \mathrm{Ma}$ and the overlying $\sim 2 \mathrm{~km}$ thick insulating sediment section on the incoming oceanic crust result in unusually high temperatures in the subducting slab. Most of the incoming sediment section appears to be scraped off at the deformation front ("trench") (Davis and Hyndman, 1989). The plate configuration and convergence have been reasonably stable for the past several $10 \mathrm{~s} \mathrm{~m} \mathrm{yr}^{-1}$ (e.g. Riddihough and Hyndman, 1991) so the temperatures can be approximated as nearly steady state, although the subducting plate age was probably somewhat older for much earlier times. A major margin structure reorganization occurred in the Eocene, $\sim 43 \mathrm{Ma}$, with a probable seaward jump in the axis of subduction. The regional structure of the forearc

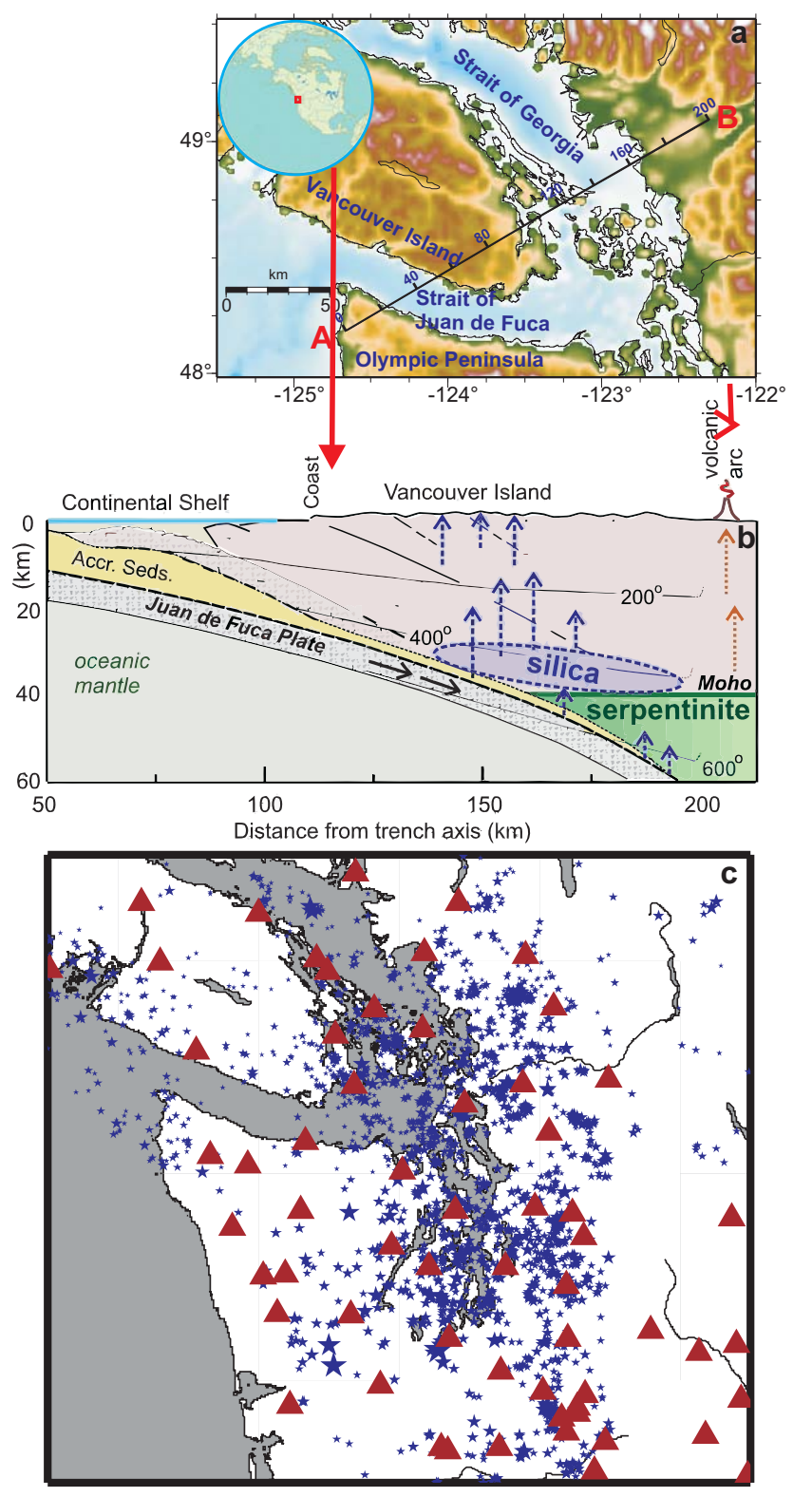

Fig. 1. (a) Location map of the study region. Distance along the profile is marked in kilometers. (b) schematic along line AB showing the subduction zone structure. (c) map view of stations and earthquakes used in tomography. Vertical cross-sections of P- and S-wave velocity along profile AB are shown in Fig. 4.

is quite well defined by seismic and other geophysical data (e.g. Hyndman et al., 1990). The depth to the Cascadia forearc Moho beneath southwestern British Columbia is $\sim 36 \mathrm{~km}$ (Cassidy and Ellis, 1993; Zhao 2001 et al., 2001; Ramachandran et al., 2006, Brocher et al., 2003). 
Many authors have concluded that large amounts of fluids are carried into the mantle by subducting slabs (e.g. Peacock, 1990). The estimated fluid expulsion rate from the subducting Juan de Fuca slab beneath the Cascadia forearc mantle is 1 to $2 \times 10^{-4} \mathrm{~m}^{3} \mathrm{~m}^{-2} \mathrm{yr}^{-1}$ (e.g. Hyndman and Peacock, 2003). The release rate of slab fluids used in our paper is given by Hyndman and Peacock (2003, Fig. 5) along with the dehydration reactions involved. The fluid expulsion rate is roughly constant from the forearc mantle corner landward for about $150 \mathrm{~km}$. The most important dehydration reaction under the forearc is predicted to be basalt garnet dehydration and high-temperature basalt dehydration. Hacker et al. (2003) give a similar number for a "warm subduction" zone, but apparently not for Cascadia. The expelled fluids are inferred to rise, hydrate, and serpentinize the forearc mantle peridotite. Serpentinization of cool forearc mantle by rising fluids has been recognized quite widely, especially in young, hot subduction zones (e.g. Hyndman and Peacock, 2003; Graeber and Asch, 1999; Brocher et al., 2003; Kamiya and Kobayashi, 2000; Blakely et al., 2005; Bostock, 2002). The path of the rising fluids is not known, and we have assumed that they move upward approximately vertically.

\section{Seismic tomography methods and data}

In this article, we report results from a $\mathrm{P}$ - and S-wave tomography study. A 3-D travel-time tomographic inversion was used to construct $\mathrm{P}$ - and $\mathrm{S}$-wave minimum structure velocity models, based on $55000 \mathrm{P}$-wave travel-time picks and 28000 S-wave travel time picks recorded at 91 stations for approximately 2500 earthquakes. The velocity model was parameterized in the forward and inverse directions with a node and cell spacing of $(2 \times 2 \times 2) \mathrm{km}$ and $(4 \times 4 \times 2) \mathrm{km}$, respectively. The P-wave velocity model and relocated hypocentral parameters were estimated using the regularized non-linear inversion method (Ramachandran et al., 2005; Zelt and Barton, 1998). Since we are interested in estimating S-wave velocity, and Poisson's ratio in this study, we have utilized the following data modeling approach to obtain unbiased Pand S- velocity estimates for calculating Poisson's ratio. Our data modeling approach for estimating shear wave velocities from earthquake tomography data is similar to the approach described by Sun et al. (2008).

Step 1: An initial 1-D P-wave velocity model was constructed using the average 1-D model obtained from the previously constructed regional velocity model discussed in Ramachandran et al. (2006). This 1-D velocity model, along with controlled source travel time picks from Seismic Hazards Investigation in Puget Sound experiment (Ramachandran et al., 2006) and P-wave travel-time picks from the selected earthquakes were first employed to relocate hypocenters and estimate a preliminary P-wave 3-D velocity model. The algorithm used in this study is described in Ramachandran et al. (2005) and references therein.
Step 2: In this step, we constructed a velocity model using P-wave earthquake picks only. For this, hypocentral locations obtained from the previous step, along with an average 1-D model derived from the 3-D model constructed in the previous step, and $\mathrm{P}$-wave traveltime picks from earthquakes were used to construct a final P-wave velocity model. In this step hypocentral positions are kept fixed.

Step 3: In this step, an initial 1-D S-wave velocity model was constructed using an average 1-D P-wave velocity model obtained from the previous step and a $\mathrm{Vp} / \mathrm{Vs}$ ratio of 1.75 . Using this 1-D S-wave velocity model, relocated hypocentral locations, and the S-wave travel time picks a preliminary 3-D $\mathrm{S}$-wave velocity model was constructed.

Step 4: From the preliminary S-wave velocity model constructed in the previous stage, an average 1-D S-wave velocity model was constructed. Using this average 1-D velocity model as starting model, a final S-wave velocity model was constructed. The above mentioned approach to construct a 3D S-wave velocity model is expected to remove bias that may have been incorporated by the assumption made previously on $\mathrm{Vp} / \mathrm{Vs}$ ratio.

The RMS misfit for the P- and S-wave travel-time data in the initial model was $551 \mathrm{~ms}$ and $727 \mathrm{~ms}$, respectively. The RMS travel-time misfit for P- and S-wave travel-time data in the final model was $207 \mathrm{~ms}$ and $282 \mathrm{~ms}$, respectively. Plots showing traveltime misfits (residuals) in starting and final models are shown in Fig. 2.

\subsection{Checkerboard tests}

Using the approach of Zelt and Barton (1998), a synthetic velocity model was generated by the addition of a laterally and vertically alternating anomaly pattern of positive and negative squares $(32 \mathrm{~km} \times 32 \mathrm{~km} \times 8 \mathrm{~km})$ to the final velocity model obtained by tomographic inversion. The hypocenterstation geometry and the synthetic velocity models were then used to compute synthetic traveltimes. Gaussian noise with a standard deviation equal to the estimated uncertainties in the earthquake traveltime picks was added to the computed traveltimes. These synthetic traveltime data were then inverted using the final velocity model as the starting model. The recovered anomaly pattern is shown by one horizontal slice and two E-W vertical cross sections in Fig. 3. The results indicate a horizontal resolution of at least $32 \mathrm{~km}$ and vertical resolution of $8 \mathrm{~km}$. The vertical resolution indicated by the checkerboard test is sufficient to discuss the low Poisson's ratio anomaly mapped in the lower crust and the higher Poisson's Ratio in the forearc upper mantle.

\section{Results}

Good seismograph station distribution and a wide distribution of earthquakes in the immediately underlying subducting slab and in the overlying continental forearc crust have 

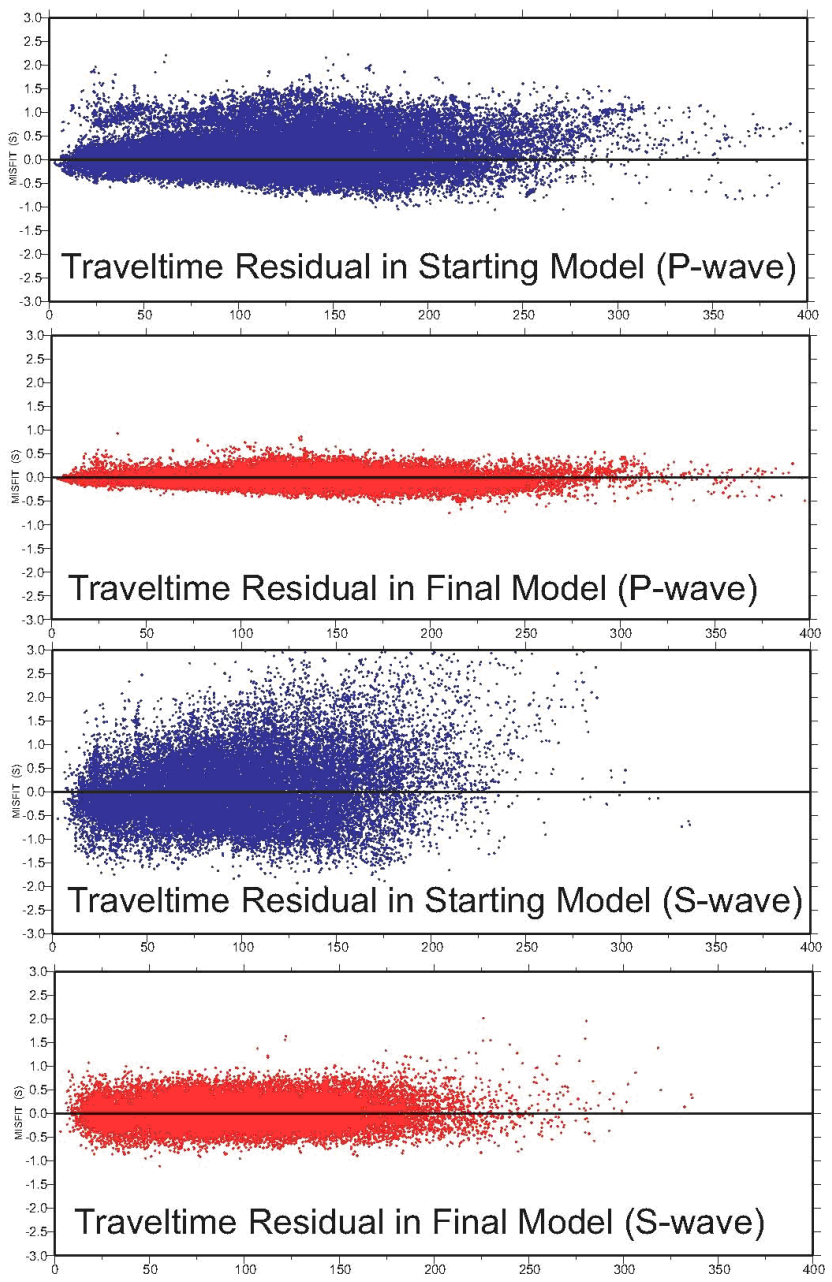

Fig. 2. $\mathrm{P}$ - and $\mathrm{S}$-wave traveltime misfits in starting model and final model.

allowed exceptionally high-resolution tomographic velocities. P- and S-wave velocity cross-sections along profile $\mathrm{AB}$ (Fig. 1) are shown in Fig. 4a and b, respectively. The cross-section of $\sigma$ computed from $\mathrm{P}$ - and $\mathrm{S}$-wave velocity along profile $A B$ is shown in Fig. 4c. The inferred positions of the Juan de Fuca slab and the forearc mantle are shown on the cross-sections. The location of the slab mapped in the present study from $\mathrm{S}$-wave velocity is consistent with the position of the slab inferred in previous tomographic $\mathrm{P}$-wave velocity models by Ramachandran et al. (2006). The P- and S-wave velocity models from the present study distinctly image the position of the forearc mantle.

The two results of particular interest are the high Poisson's ratios in the forearc mantle wedge and low Poisson's ratios at the base of the overlying forearc crust. The forearc mantle wedge has low P-wave velocities of $7.4-7.8 \mathrm{~km} \mathrm{~s}^{-1}$, and S-wave velocities of $4.1-4.4 \mathrm{~km} \mathrm{~s}^{-1}$, which, as we discuss below, is strongly indicative of a high degree of serpentinization. We interpret the low Poisson's ratios in the lower forearc crust as concentrations of quartz, the only common mineral that has a very low Poisson's ratio.

\section{Forearc mantle serpentinization}

Many authors have concluded that large amounts of fluids are carried into the mantle by subducting slabs (e.g. Peacock, 1990). The expelled fluids are inferred to rise, hydrate, and serpentinize the forearc mantle peridotite. However, we recognize that low velocities in the mantle wedge can also be attributed to (1) presence of chlorite with antigorite, (2) anisotropy of partially serpentinized peridotite, and (3) high pore pressure (Christensen, 2004). Most of these processes are unlikely to produce velocities as low as those we observed. Of the main serpentine minerals, chrysotile and lizardite have similar composition and elastic properties, and are stable below about $300^{\circ} \mathrm{C}$. Antigorite is the stable species of serpentine at forearc mantle P-T conditions. In this study, we employed the elastic properties of peridotite and antigorite to estimate the amount of serpentine in the forearc mantle.

In spite of the young hot incoming plate, the Cascadia forearc is relatively cool as a consequence of heat removed by the subduction of cool, near surface oceanic crust. The observed heat flow in this region is in good agreement with the subduction thermal model (e.g. Hyndman and Wang, 1995; Hacker et al., 2003). Calculated forearc mantle temperatures in this region are $400-600{ }^{\circ} \mathrm{C}$. The thermal model used in our study is that shown in Fig. 3 of Hyndman and Peacock (2003). The computation is given by Hyndman and Wang (1995). Hyndman and Peacock (2003) provide detailed discussion of different dehydration temperatures.

The tomographic P-wave velocity imaged in the uppermost northern Cascadia forearc mantle is anomalously low, compared to the normal Pn velocity of $8.15-8.25 \mathrm{~km} \mathrm{~s}^{-1}$ in stable continental areas, for an estimated Moho temperature of 350-450 ${ }^{\circ} \mathrm{C}$ (e.g. Hyndman and Peacock, 2003). For computing the degree of upper mantle serpentinization in this region from the imaged tomographic velocities, $\mathrm{Vp}$ of unaltered peridotite was taken to be the average Pn velocity for cool stable areas of $8.2 \mathrm{~km} \mathrm{~s}^{-1}$ (Christensen and Mooney, 1995). Employing a Vp/Vs value of 1.75 , the unaltered upper mantle Vs was taken as $4.7 \mathrm{~km} \mathrm{~s}^{-1}$. Vp and Vs values of antigorite at $1 \mathrm{GPa}$ and $500 \mathrm{C}$ were taken from Christensen (2004). The plot of peridotite-antigorite velocity versus volume percent serpentinization is shown in Fig. 5. Estimates of mantle serpentinization from $\mathrm{Vp}\left(7.4-7.8 \mathrm{~km} \mathrm{~s}^{-1}\right)$ and $\mathrm{Vs}$ $\left(4.1-4.4 \mathrm{~km} \mathrm{~s}^{-1}\right)$ are in good agreement and indicate 20 $45 \%$ serpentinization in the mantle wedge (Fig. 5). The percent serpentinization in the forearc mantle-wedge computed from P- and S-wave velocities (Fig. 6a and b) show higher levels of serpentinization near the slab-forearc mantle corner, $\sim 45 \%$, decreasing landward to about $20 \%$ approaching 

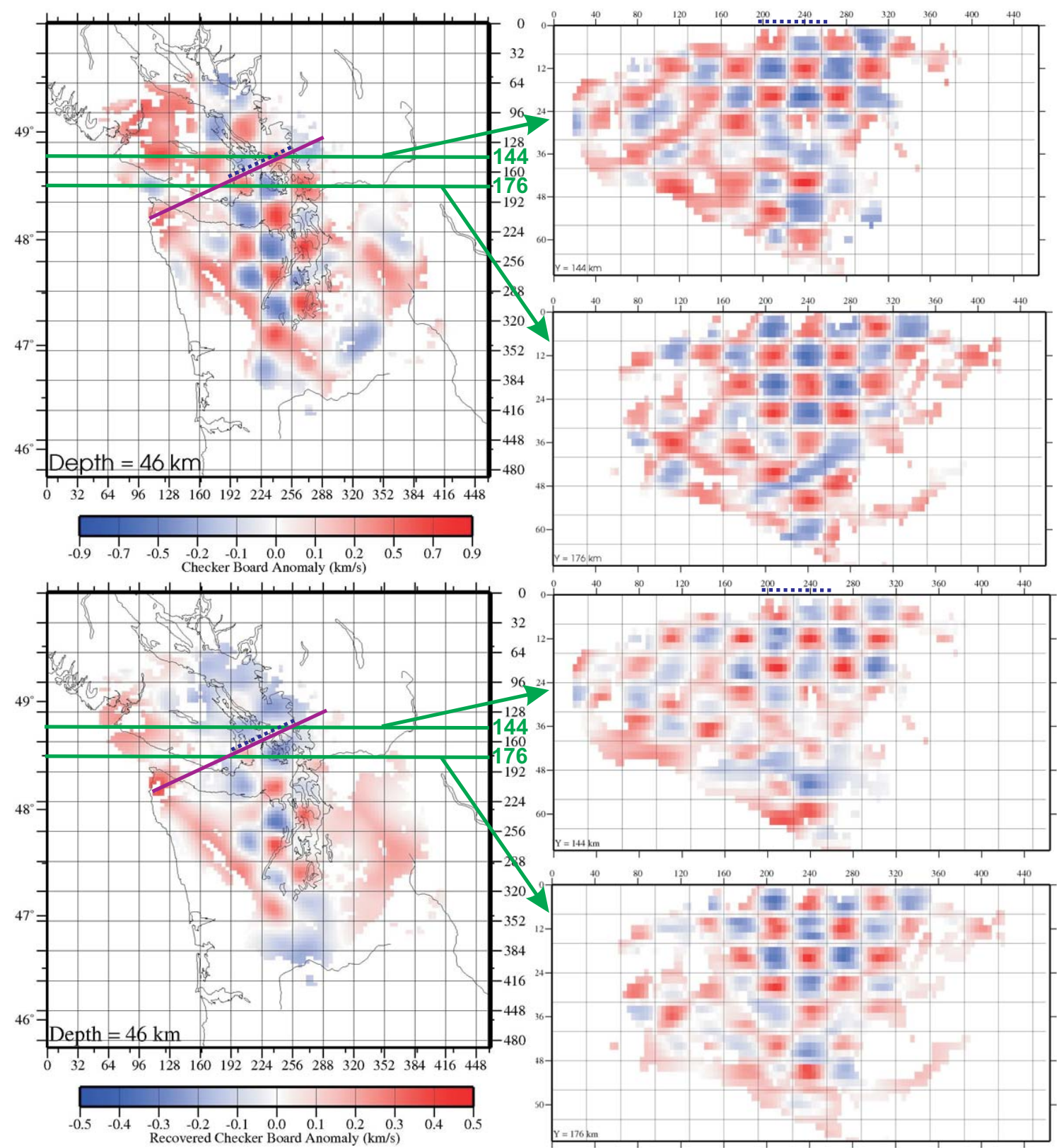

Fig. 3. Recovered P-wave (top) and S-wave (bottom) checkerboard anomaly pattern $(32 \mathrm{~km} \times 32 \mathrm{~km} \times 8 \mathrm{~km})$ for estimating horizontal and vertical resolution is shown in the figure by one horizontal slice at $46 \mathrm{~km}$ depth (shown on the left) and two E-W vertical slices (close to the main profile) at distances of $144 \mathrm{~km}$ and $176 \mathrm{~km}$ positions in the $\mathrm{N}-\mathrm{S}$ direction (shown on the right). Purple line marks the position of the main cross-section discussed in the main article. Blue dotted line shows the inferred position of the forearc mantle wedge.

the volcanic arc (Fig. 6c). Lack of detailed knowledge on the other processes that may be responsible for lowering of forearc mantle velocities precludes the possibility of estimating their contribution to lowering velocities.

Complete alteration of peridotite to pure serpentine increases the bound water content by $\sim 13 \mathrm{wt} \%$, and the variation of water content with velocity is nearly linear (e.g. Carlson and Miller, 2003). In our study, the computed mantle wedge serpentinization of $20-45 \%$ indicates $2-6 \mathrm{wt} \%$ water content in the forearc mantle. At $500^{\circ} \mathrm{C}$ and $1 \mathrm{GPa}$, the density of water is $1010 \mathrm{~kg} \mathrm{~m}^{-3}$ (e.g. Verma, 2003), and the total water content computed for a unit column of the forearc mantle ranges from $500 \mathrm{~m}^{3} \mathrm{~m}^{-2}$ near the mantle wedge corner to $2500 \mathrm{~m}^{3} \mathrm{~m}^{-2}$ approaching the arc (Fig. 6c). The updip and downdip transport path of the fluids is not known, but if expelled vertically upward, most of the fluid produced in the 

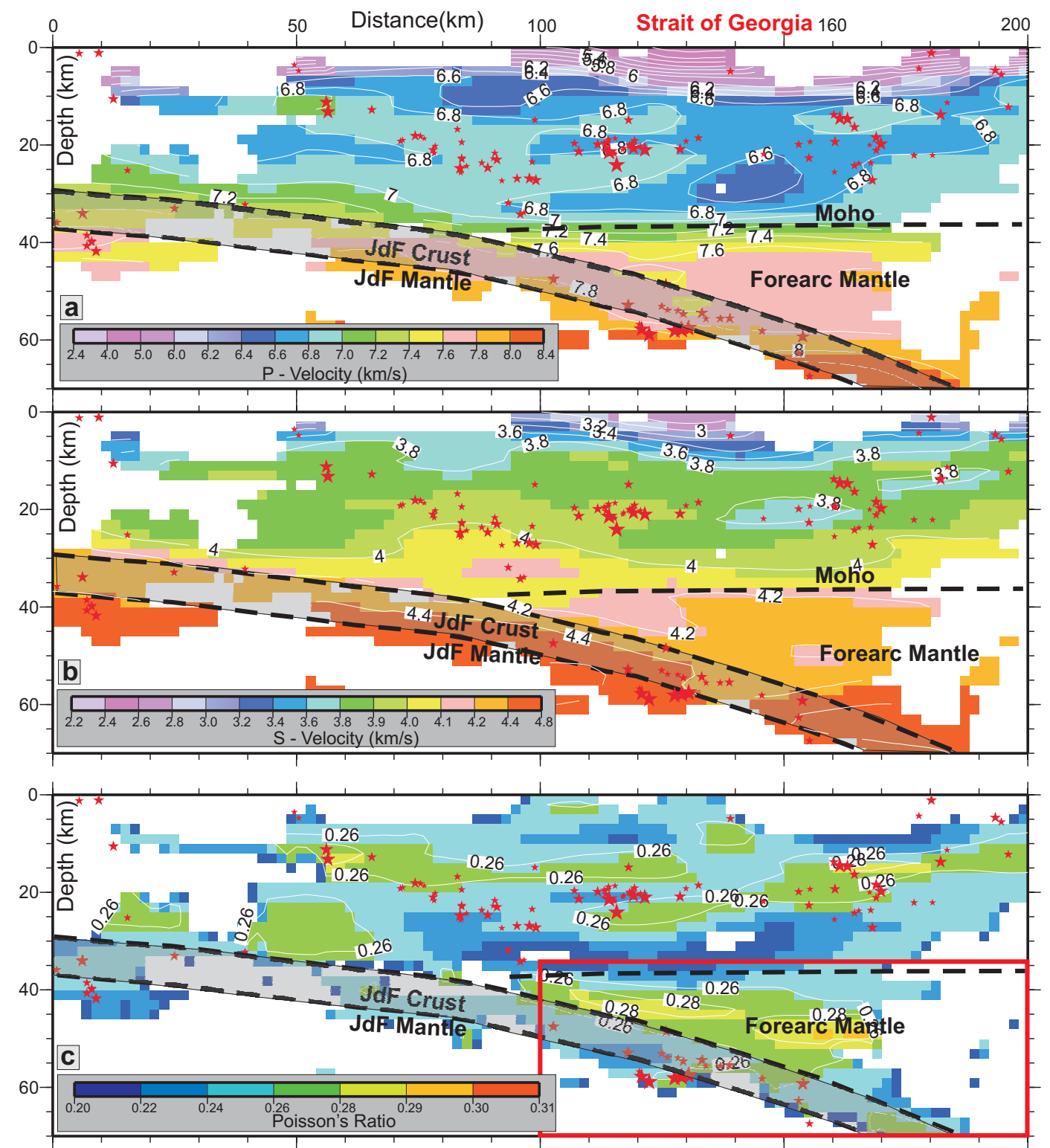

Fig. 4. Vertical cross-section along profile AB showing (a) P-wave velocity, (b) S-wave velocity, and (c) Poisson's ratio. Earthquake hypocenters within $10 \mathrm{~km}$ of the profile are plotted on the cross-sections as red stars. The red box in Fig. 4c shows the region for which volume percent serpentinization is shown in Fig. 6.

$\sim 40 \mathrm{~m} \mathrm{yr}^{-1}$ of current phase of subduction will be trapped in the overlying thicker part of the forearc mantle. Hyndman and Peacock (2003) calculated an upward fluid expulsion rate of about $0.1 \mathrm{~mm} \mathrm{yr}^{-1}$ from the dehydrating subducting plate underlying the forearc mantle of SW Japan (Fig. 6), which is slightly cooler but has very similar thermal regime to Cascadia. In the $\sim 40 \mathrm{~m} \mathrm{yr}^{-1}$ since the last major margin plate reorganization, this rate gives a total upward flux of $\sim 4000 \mathrm{~m}^{3} \mathrm{~m}^{-2}$, which is about double that we estimate to be now in the Cascadia forearc mantle. Considering the uncertainties in upward flux, in whether the flux is vertical, and in our fraction serpentinization, this is reasonable agreement. Toward the thin corner of the forearc mantle, most of the water is expected to rise into the overlying forearc crust.

\section{Low Poisson's ratio in the deep forearc crust and silica deposition}

A striking feature of an area at the base of the deep forearc crust is a $\sim 10 \mathrm{~km}$ thick layer with Poisson's ratio that is unusually low, $0.20-0.24$. This region lies over the seaward part of the forearc mantle wedge and extends further seaward of 


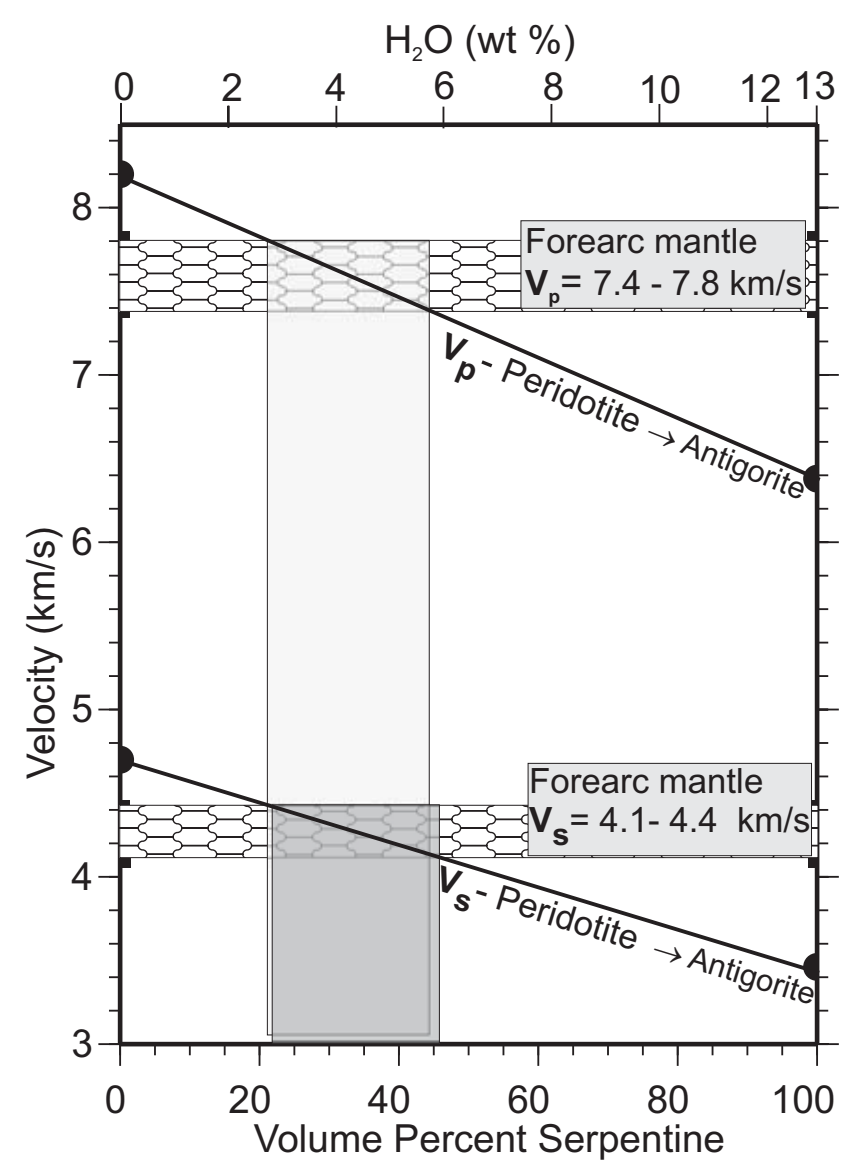

Fig. 5. Plot of peridotite-antigorite assemblage velocity versus volume percent serpentinization (velocity of antigorite taken from (Christensen, 2004)). The observed range of P- and S-wave velocity is shown by the hachured region. The vertical shaded regions show the volume serpentinization corresponding to the observed $\mathrm{P}$ and $\mathrm{S}$ velocity range.

the mantle corner. These $\sigma$ values are much lower than the common range of values obtained in the global compilation of Zant and Ammon (1995) and in the Cordillera to the east (e.g. Clowes et al., 1995).

Very few minerals have such low $\sigma$. The only common mineral with low Poisson's ratio is quartz, which is exceptionally low ( $\sigma \sim 0.1)$ (Christensen, 1996), and we postulate high quartz concentrations for the observed low Poisson's ratio. Using Poisson's ratios of quartz $(\sigma=0.1)$ and normal lower crust (0.26), the volume \% quartz estimated for an observed $\sigma$ of $\sim 0.22$ in this region is $\sim 20 \%$, assuming a simple linear relation between Poisson's ratio and quartz content. We recognize that there may be significant anisotropy either as sills, subvertical veins, or grain anisotropy, so this is only a semi-quantitative estimate. Silica rich rocks are not normally indicated in the lower continental crust, but in the special environment of the forearc they may be expected (e.g. Manning, 1996), for which there is previous evidence.

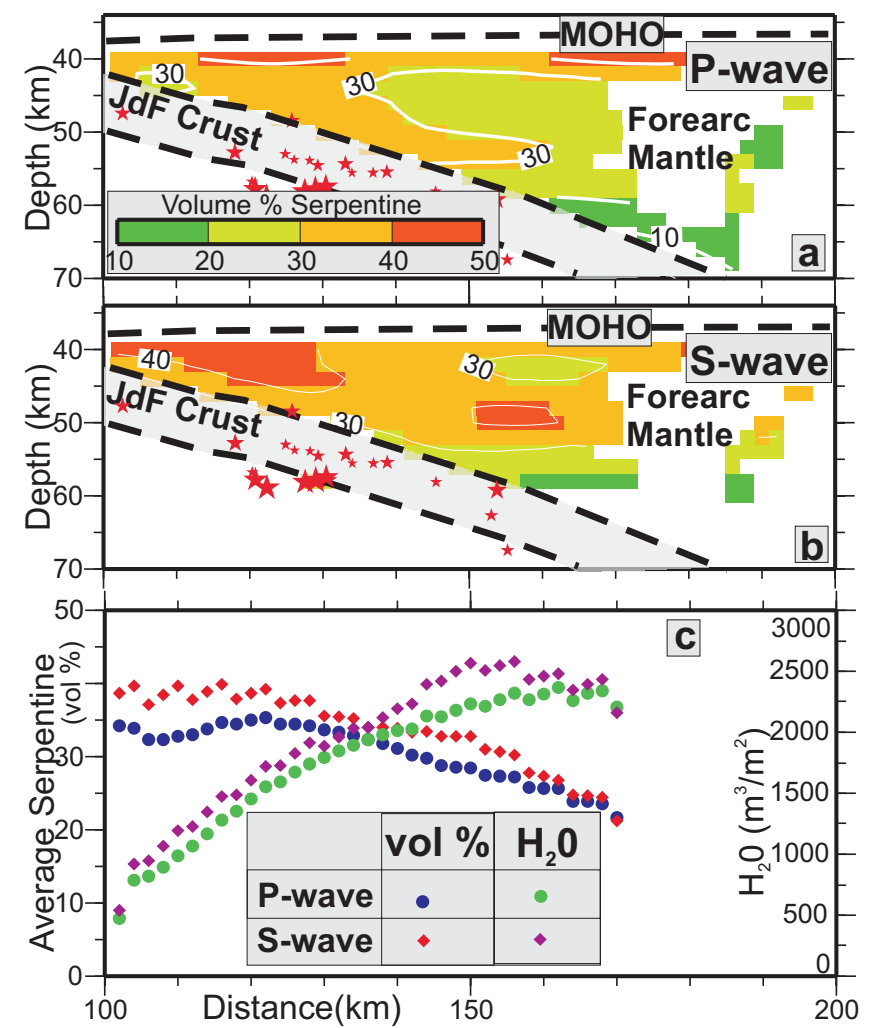

Fig. 6. Plot of volume percent serpentinization in the forearc mantle computed from (a) P-wave velocity and (b) S-wave velocity for the region enclosed by the red box in Fig. 4c (100-200 km distance on profile AB shown in Fig. 1). (c) Plot of average volume \% serpentine and total water content in a unit column of the forearc mantle.

In an especially relevant study, quartz deposited in the deep forearc from silica-rich fluids rising from the subducted slab was described by Breeding and Ague (2002). Although their study was for the landward part of a very thick accretionary sedimentary prism, the depth of deposition and greenschist facies P-T conditions of $350-450^{\circ} \mathrm{C}$ and $600-800 \mathrm{MPa}(6-$ $8 \mathrm{kbar}$ ) are similar to the region of our low Poisson's ratio of $\sim 400^{\circ} \mathrm{C}$ (e.g. Hyndman and Wang, 1995; Hacker et al., 2003). Breeding and Ague (2002) found about $4 \%$ mass increase from quartz veins in their deep section, lower than the $\sim 20 \%$ that appears to be required to explain our observed low Poisson's ratio.

Fluids rising from the downgoing oceanic plate are very likely to be silica saturated (e.g. Manning, 1996; Peacock and Hyndman, 1999). Since the solubility of silica is strongly temperature dependent, most of the silica will be rapidly removed and deposited in the crust above the subducted slab. The silica solubility decreases by about a factor of four as temperatures decrease upward from 500 to $400{ }^{\circ} \mathrm{C}$ (Manning, 1994), so most of the silica will be removed near the base of the crust. 


\section{Discussion}

The $\mathrm{Vp}$ and $\mathrm{Vs}$ data give almost identical estimates of degree of serpentinization in the forearc mantle of the northern Cascadia subduction zone. The concentrations are highest at the tip of the mantle wedge, about $40 \%$, decreasing landward to 20-30\% approaching the volcanic arc. However, the mantle wedge thickness increases landward such that the total water in a vertical column increases landward by a factor of $\sim 4$ from where the wedge is $\sim 5 \mathrm{~km}$ thick to where it is $\sim 25 \mathrm{~km}$ thick, in spite of the decreasing serpentinite concentrations. We infer that much of the rising water transits through the seaward part of the forearc mantle, but much of it is trapped in the landward part.

For our second tracer of rising fluid from the subducted plate, low Poisson's ratio layer is well resolved. There are no common minerals except quartz with very low Poisson's ratio. A good case has been made previously that the fluids rising off the downgoing plate are silica saturated, and the rapid decrease in solubility with upward decreasing temperature is well established. Therefore silica deposition in the forearc is expected. However, our estimated amount of $\sim 20 \%$ silica requires greater upward fluid expulsion than that estimated for the $\sim 40 \mathrm{~m} \mathrm{yr}^{-1}$ current phase of subduction. The field observation of high concentrations of quartz veins in a similar position in an exposed deep subduction zone section by Breeding and Ague (2002) gives some confidence that our interpretation is correct.

There are important consequences of the presence of substantial amounts of serpentinite in the forearc mantle, and of a silica rich lower crust layer subsequent to continental collision and in orogeny. First, the serpentinite provides a substantial source of water in the orogenic belt and perhaps to the rheology of the deforming zone. The addition of a silica rich layer will play a role in the overall composition of the continental crust. It usually has been assumed that the mafic arc volcanic rocks are the primary accretion material that extends the volume of continental crust. However, Taylor and McLennan (1996) have argued that the average continental crust could not have achieved its current high average silica content through magmatic differentiation of such rocks. If our estimate of silica deposited is correct and is applicable to many forearcs, it represents a significant addition of silica to the lowermost crust making the accreted crust more felsic and to silica enrichment of the continents, as argued, for example, by Breeding and Ague, (2002).

We have focussed on Cascadia, which is subducting a hot, young lithosphere. Subduction zones with older and faster incoming oceanic plates are colder and much of the water must be dehydrated and released at greater depths. There may be less water released into the forearc, and more into the arc and backarc. Therefore, serpentinization of the forearc mantle may be slower and the formation of lower crust silica slower for old and cold incoming plates.
Acknowledgements. The first author would like to thank The University of Tulsa for providing research support through start-up funds. All figures were made using the Generic Mapping Tools (Wessel and Smith, 1991, 1995).

Special Issue: "Subduction zones"

Edited by: S. Buiter, F. Funiciello, and J. van Hunen

\section{References}

Blakely, R. J., Brocher, T. M., and Wells, R. E.: Subduction zone magnetic anomalies and implications for hydrated forearc mantle, Geology, 33, 445-448, doi:10.1130/G21447.1, 2005.

Bounama, C., Franck, S., and von Bloh, W.: The fate of Earths ocean, Hydrol. Earth Syst. Sci., 5, 569-576, doi:10.5194/hess-5569-2001, 2001.

Bostock, M. G., Hyndman, R. D., Rondenay, S., and Peacock, S. M.: An inverted continental Moho and the serpentinization of the forearc mantle, Nature, 417, 536-538, 2002.

Breeding, C. M. and Ague, J. J.: Slab-derived fluids and quartz-vein formation in an accretionary prism, Otago Schist, New Zealand, Geology, 30, 499-502, 2002.

Brocher, T. M., Parsons, T., Trehu, A. M., Snelson, C. M., and Fisher, M. A.: Seismic evidence for widespread serpentinized forearc upper mantle along the Cascadia margin, Geology, 31, 267-270, 2003.

Carlson, R. L. and Miller, D. J.: Mantle wedge water contents estimated from seismic velocities in partially serpentinized peridotites, Geophys. Res. Lett., 30, 1250, doi:10.1029/2002GL016600, 2003.

Cassidy, J. F. and Ellis, R. M.: S-wave velocity structure of the northern Cascadia subduction zone, J. Geophys. Res., 98, 44074421, 1993.

Christensen, N. I.: Poisson's ratio and crustal seismology, J. Geophys. Res., 101, 3139-3156, 1996.

Christensen, N. I.: Serpentines, Peridotites \& Seismology, International Geology Review, 46, 795-816, 2004.

Christensen, N. I. and Mooney, W. D.: Seismic velocity structure and composition of the continental crust: A global view, J. Geophys. Res., 100, 9761-9788, 1995.

Clowes, R. M., Zelt, C. A., Amor, J. R., and Ellis, R. M.: Lithospheric structure in the southern Canadian Cordillera from a network of seismic refraction lines, Can. J. Earth Sci., 32, 14851513, 1995.

Davis, E. E. and Hyndman, R. D.: Accretion and Recent deformation of sediments along the northern Cascadia subduction zone, GSA Bulletin, Nov., 101, 465-1480., 1989.

Graeber, F. and Asch, G.: Three-dimensional models of $\mathrm{P}$ wave velocity and P-to-S velocity ratio in the southern central Andes by simultaneous inversion of local earthquake data, J. Geophys. Res., 104, 20237-20256, 1999.

Hacker, B. R., Abers, G. A., and Peacock, S. M.: Subduction factory 1 . Theoretical mineralogy, densities, seismic wave speeds, and $\mathrm{H}_{2} \mathrm{O}$ contents, J. Geophys. Res., 108, 2029, doi:10.1029/2001JB001127, 2003.

Hyndman, R. D. and Peacock, S. M.: Serpentinization of the forearc mantle, Earth Planet. Sc. Lett., 212, 417-432, 2003. 
Hyndman, R. D. and Wang, K.: The rupture zone of Cascadia great earthquakes from current deformation and the thermal regime, J. Geophys. Res., 100, 22133-22154, doi:10.1029/95JB01970, 1995.

Hyndman, R. D., Yorath, C. J., Clowes, R. M., and Davis, E. E.: The northern Cascadia subduction zone at Vancouver Island: Seismic structure and tectonic history, Can. J. Earth Sci., 27, 313-329, 1990.

Ingebritsen, S. E. and Manning, C. E.: Diffuse fluid flux through orogenic belts: Implications for the world ocean, Proc. Nat. Acad. Sci., USA, 99, 9113-9116, 2002.

Jambon, A.: Earth degassing and large-scale geochemical cycling of volatile elements, Rev. Min. and Geochem., 30, 479-517, 1994.

Kamiya, S. and Kobayashi, Y.: Seismological evidence for the existence of serpentinized wedge mantle, Geophys. Res. Lett., 27, 819-822, 2000.

Manning, C. E.: The solubility of quartz in H20 in the lower crust and upper mantle, Geochem. Cosmochem. Acta, 58, 4831-4839, 1994.

Manning, C. E.: Effect of sediments on aqueous silica transport in subduction zones, in: Subduction: Top to Bottom, edited by: Bebout, G. E., Scholl, D. W., Kirby, S. H., and Platt, J. P., Geophys Monogr. 96, Am. Geophys. Un., 277-284, 1996.

Peacock, S. M.: Fluid processes in subduction zones, Science, 248, 329-337, 1990.

Peacock, S. M. and Hyndman, R. D.: Hydrous minerals in the mantle wedge and the maximum depth of subduction zone earthquakes, Geophys. Lett., 26, 2517-2520, 1999.

Ramachandran, K., Dosso, S. E., Spence, G. D., Hyndman, R. D., and Brocher, T. M.: Forearc structure beneath southwestern British Columbia: A three-dimensional tomographic velocity model, J. Geophys. Res., 110, B02303, doi:10.1029/2004JB003258, 2005.

Ramachandran, K., Hyndman, R. D., and Brocher, T. M: Regional $P$ wave velocity structure of the Northern Cascadia subduction zone, J. Geophys. Res., 111, B12301, doi:101029/2005Jb00408J, 2006.

Riddihough, R. P. and Hyndman, R. D.: Modern plate tectonic regime of the continental margin of western Canada, in: Geology of the Cordilleran Orogen in Canada, edited by: Gabrielse, H. and Yorath, C. J., Geology of Canada, 4, 435-455, Geological Survey of Canada, 1991.
Rupke, L. H., Phipps Morgan, J., and Connolly, H.: Serpentine and the subduction zone water cycle, Earth Planet Sci. Lett., 223, 1734, 2004.

Savov, I. P., Ryan, J. G, D’Antonio, M., Fryer, P.: Shallow slab fluid release across and along the Mariana arc-basin system: Insights from geochemistry of serpentinized peridotites from the Mariana Forearc, J. Geophys. Res., 112, B09205, doi:10.1029/2006JB004749, 2007.

Schmidt, M. W. and Poli, S.: Experimentally based water budgets for dehydrating slabs and consequences for arc magma generation, Earth Planet. Sci. Lett., 163, 361-379, 1998.

Sun, Y., Tokso“z, M. N., Pei, S., Zhao, D., Morgan, F. D., and Rosca, A.: $\mathrm{S}$ wave tomography of the crust and uppermost mantle in China, J. Geophys. Res., 113, B11307, doi:10.1029/2008JB005836, 2008.

Taylor, S. R. and McLennan, S. M.: The evolution of continental crust, Scientific American, 274, 1, 76-81, 1996.

Verma, M. P.: Steam tables for pure water as an ActiveX component in Visual Basic 6.0, Computers and Geosciences, 29, 1155-1163, 2003.

Wessel, P. and Smith, W. H. F.: Free software helps map and display data, EOS Trans. AGU, 72, 441, 1991.

Wessel, P. and Smith, W. H. F.: New Version of the Generic Mapping Tools Released, EOS Trans. AGU, 76, 329, 1995.

Xia, S., Zhao, D., and Qiu, X.: Tomographic evidence for the subducting oceanic crust and forearc mantle serpentinization under Kyushu, Japan, Tectonophysics, 449, 85-96, 2008.

Zandt, G. and Ammon, C. J.: Continental crust composition constrained by measurements of crustal Poisson's ratio, Nature, 374, 152-154, 1995.

Zelt, C. A. and Barton, P. J.: 3-D Seismic refraction tomography: A comparison of two methods applied to data from the Faroe basin, J. Geophys. Res., 103, 7187-7210, 1998.

Zhao, D., Wang, K., Rogers, G. C., and Peacock, S. M.: Tomographic image of low $\mathrm{P}$ velocity anomalies above slab in northern Cascadia subduction zone Earth Planets Space, 53, 285-293, 2001.

Zhao, D., Wei, W., Nishizono, Y., and Inakura, H.: Low-frequency earthquakes and tomography in western Japan: Insight into fluid and magmatic activity, J. Asian Earth Sci., 42, 1381-1393, 2011. 